\title{
Solid state amorphization in a thin Fe-Si-Mg-O surface film triggered by the reduction of elements from oxides in the temperature range of the $\alpha-\gamma$ transformation
}

\author{
M. L. Lobanov ${ }^{\dagger, 1,2}$, A.S. Yurovskikh ${ }^{1}$, P.L. Reznik ${ }^{1}$, N. N. Nikul'chenkov ${ }^{1}$, \\ G. M. Rusakov ${ }^{1,2}$, A. A. Redikul'tsev ${ }^{1}$ \\ †m.1.lobanov@urfu.ru \\ ${ }^{1}$ Ural Federal University n. a. the first President of Russia B. N. Yeltsin, 19 Mira St., Yekaterinburg, 620002, Russia \\ ${ }^{2}$ M. N. Miheev Institute of Metal Physics UB RAS, 18 S. Kovalevskaya St., Yekaterinburg, 620990, Russia
}

\begin{abstract}
The study of the processes occurring in the surface layer of the $\mathrm{MgO}$ coated commercial alloy $\mathrm{Fe}-3 \% \mathrm{Si}-0.5 \% \mathrm{Cu}$ (grain oriented electrical steel) demonstrated that the amorphous phase in the form of a Fe-based solid solution is formed during continuous heating in the $95 \% \mathrm{~N}_{2}+5 \% \mathrm{H}_{2}$ atmosphere. For the purposes of this study, the following methods were used: nonambient $\mathrm{XRD}$ at $20-1060^{\circ} \mathrm{C}$ with heating and cooling at a rate of $0.5 \mathrm{dps}$, layer-by-layer chemical analysis performed by a glow discharge analyzer, scanning electron microscopy and energy dispersive X-ray spectroscopy. ThermoCalc software was used to calculate the potential phase equilibrium states. The amorphous phase was formed in the $\alpha \rightarrow \gamma$ transformation temperature range, when the heating rates were altered in the surface layer of $1 \mu \mathrm{m}$ initially consisted of a solid $\alpha$-Fe-based solution with 1-2 wt.\% $\mathrm{Si}$ with $(\mathrm{MgFe})_{2} \mathrm{SiO}_{4},(\mathrm{MgFe}) \mathrm{O}, \mathrm{SiO}_{2}$ oxide inclusions. We suppose that $(\mathrm{MgFe})_{2} \mathrm{SiO}_{4}$ oxides are partly reduced by $\mathrm{H}_{2}$ to $\mathrm{Mg}_{2} \mathrm{Si}$ molecular complexes, which become solid solutions in the temperature range of the metastability of the $\alpha-\mathrm{Fe}$ crystal lattice with subsequent amorphization as an alternative to the $\alpha \rightarrow \gamma$ transition. The amorphous state is obtained at $920-960^{\circ} \mathrm{C}$ and is retained both at subsequent heating $\left(\right.$ to $1060^{\circ} \mathrm{C}$ ) and cooling (to $20^{\circ} \mathrm{C}$ ), which is super-stable compared to the established metallic glasses. The composition of the amorphous phase can be described by the formula $\mathrm{Fe}_{89.5} \mathrm{Si}_{6} \mathrm{Mg}_{4} \mathrm{Cu}_{0.5}$.
\end{abstract}

Keywords: metallic glasses, solid-state amorphisation, X-ray diffraction, phase transitions.

УДК: 53.087.3:543.423

Аморфизация из твердого состояния в тонкой поверхностной пленке Fe-Si-Mg-O, инициированная восстановлением элементов из оксидов в интервале температур $\alpha-\gamma$-превращения

Лобанов М. Л. ${ }^{\dagger 1,2}$, Юровских А.С. ${ }^{1}$, Резник П. Л. ${ }^{1}$, Никульченков Н. Н. ${ }^{1}$,

Русаков Г.М. ${ }^{1,2}$, Редикульцев А. А. ${ }^{1}$

1Уральский федеральный университет им. первого президента России Б. Н. Ельцина, ул. Мира, 19, Екатеринбург, 620002, Россия

${ }^{2}$ Институт физики металлов им. М. Н. Михеева УрО РАН, ул. С. Ковалевской, 18, Екатеринбург, 620990, Россия

При изучении процессов, происходящих в приповерхностной области промышленного сплава $\mathrm{Fe}-3 \% \mathrm{Si}-0.5 \% \mathrm{Cu}$ (grain oriented electrical steel) с нанесенным термостойким покрытием MgO, при непрерывном отжиге в атмосфере $95 \% \mathrm{~N}_{2}+5 \% \mathrm{H}_{2}$ было замечено образование аморфной фазы в виде твердого раствора на основе железа. При проведении исследований применялись методы: терморентгеновского анализа в интервале температур $20-1060^{\circ} \mathrm{C}$ со скоростью нагрева и охлаждения около $0.5^{\circ} / \mathrm{c}$, послойный химический анализ с использованием анализатора тлеющего разряда, сканирующая электронная микроскопия с микрорентгеноспектральным анализом. Для оценки теоретически возможных фазовых равновесий при высоких температурах использовались расчеты в программном обеспечение ThermoCalc. Образование аморфной фазы наблюдалось в приповерхностном слое глубиной приблизительно 1 мкм, исходно состоящем из твердого раствора на основе $\alpha$-Fe c 1.5 мас.\% Si и включениями 
оксидов $(\mathrm{MgFe})_{2} \mathrm{SiO}_{4},(\mathrm{MgFe}) \mathrm{O}, \mathrm{SiO}_{2}$, при нагревании в интервале температур, соответствующих превращению $a \rightarrow \gamma$, то есть $920-960^{\circ} \mathrm{C}$. Предположительно, часть оксидов $(\mathrm{MgFe})_{2} \mathrm{SiO}_{4}$ восстанавливалась $\mathrm{H}_{2}$ до молекулярных комплексов $\mathrm{Mg}_{2} \mathrm{Si}$, которые в температурном интервале метастабильности кристаллической решетки $\alpha-\mathrm{Fe}$ переходили в твердый раствор с последующей его аморфизацией, как альтернативе $\alpha \rightarrow \gamma$-превращения. Полученное при $920-960^{\circ} \mathrm{C}$ аморфное состояние сохранялось как при дальнейшем нагреве до $1060^{\circ} \mathrm{C}$, так и при последующем охлаждении до температуры $20^{\circ} \mathrm{C}$, то есть являлось сверх термически стабильным по сравнению с известными металлическими стеклами. Состав аморфной фазы можно приблизительно описать формулой $\mathrm{Fe}_{89.5} \mathrm{Si}_{6} \mathrm{Mg}_{4} \mathrm{Cu}_{0.5}$.

Ключевые слова: металлические стекла, аморфизация из твердого состояния, рентгеновский анализ, фазовые переходы.

\section{Introduction}

Since the discovery of metallic glass in 1960 [1], amorphous metallic alloys have become a completely new class of materials. Hundreds of thousands of tons of these alloys are produced annually [2]. This primarily became possible owing to the high level and/or the unique combination of different structurally dependent physical properties of these alloys (mainly magnetic and mechanical) in an extremely disordered structural state [2-3].

The formation of the atomic structure and its effect on the properties of metallic glass have been studied by a number of researchers so far [3-5]. Despite the substantial number of currently known chemical compositions of amorphous metallic glasses [6], the development of new ones [7] and the optimization of the known compositions [8] are still of considerable interest.

It is important to emphasize that Fe-based amorphous glasses are predominantly fabricated using ultra-high cooling rates providing "freezing" of atoms in a metastable structure, which does not have a long-range order [9]. Implementation of these cooling rates presents a serious problem for mass production, especially for bulk samples. Moreover, the evident instability of metallic amorphous materials during heating seriously limits the scope of their application [3].

However, Schwartz and Johnson first reported in 1983 [10] that heat treatment of an Au-La multi-layer film can lead to the formation of an amorphous state at elevated temperatures of approximately $80-120^{\circ} \mathrm{C}$. This process was called solid-state amorphization. Reactive diffusion is used for more than 20 binary amorphous alloying systems [11].

Due to their magnetic properties, Fe-, Co- and Ni-based amorphous alloys are used in the production of magnetic screens and magnetic conductors of devices designed to convert electrical energy. Due to its unique magnetic softness, the magnetic anisotropy of such materials is two orders of magnitude smaller than in traditional alloys. Ultra-thin amorphous magnetically soft tapes [3,8,12-15] produced by the melt spinning method, compete with the traditional widespread grain-oriented electrical steel (GOES), which is currently used as the main material for production of transformer cores [16].

It is noteworthy that GOES is a composite material consisting of a magnetic base (Fe-3\%Si) and an electrical insulation coating [17] represented by a multi-component film, which is formed on the surface as a result of several thermochemical operations [18]. Despite the fact that the main stages of the GOES production were developed quite a while ago [16,19-20], some details of the coating formation process are yet to be properly studied $[18,21-22]$. The small thickness of the coating of $0.5-5 \mu \mathrm{m}$ presents the main difficulty in the study of surface processes.

An interesting effect of the formation of a Fe-based amorphous phase during heating was revealed when we studied the structure and phase composition of the surface layers of $\mathrm{Fe}-3 \% \mathrm{Si}-0.5 \% \mathrm{Cu}$ alloy samples with a heat-resistant coating $(\mathrm{MgO})$.

This study aims to determine the chemical composition and establish the terms of the formation and stability of the $\mathrm{Fe}-\mathrm{Si}-\mathrm{Cu}-\mathrm{Mg}-\mathrm{O}$ amorphous phase during high temperature heat treatment.

\section{Materials and methods}

Cold-rolled $0.70 \mathrm{~mm}$-thick plates of iron-based alloy containing: $\quad 3.1 \mathrm{Si}, \quad 0.5 \mathrm{Cu}$ (wt.\%) and unavoidable precipitates. The composition of the main elements in the material corresponded to the Russian GOES production specifications $[16,23]$.

The samples were subjected to decarburizing annealing for 8 minutes in a $75 \% \mathrm{H}_{2}+25 \% \mathrm{~N}_{2}$ atmosphere humidified to the dew-point temperature of $+65^{\circ} \mathrm{C}$ [21-22]. After annealing, the carbon content did not exceed 0.002 wt.\%. Subsequently, the samples were rolled to a thickness of $0.25 \mathrm{~mm}$.

A heat-resistant coating based on a water solution of dispersed $\mathrm{MgO}$ powder was applied to the surface of the samples. After drying at $250^{\circ} \mathrm{C}$, the coating consisted of a mixture of $\mathrm{MgO}+\mathrm{Mg}(\mathrm{OH})_{2} \times \mathrm{nH}_{2} \mathrm{O}$.

The coated samples were heated in the atmosphere with $95 \% \mathrm{~N}_{2}+5 \% \mathrm{H}_{2}$. Such a protective atmosphere is utilized in the industry of the Russian Federation for annealing and can retain the oxidation level. It is obvious that the lack of $\mathrm{H}_{2} \mathrm{O}$ and the presence of $\mathrm{H}_{2}$ in the atmosphere of the furnace reduce its oxidation potential. Continuous heating was accomplished at a rate of $0.004^{\circ} \mathrm{C} / \mathrm{s}$ in the temperature range of $20-1060^{\circ} \mathrm{C}$, followed by slow cooling. At certain temperatures, sampling was carried out for testing purposes (Fig. 1).

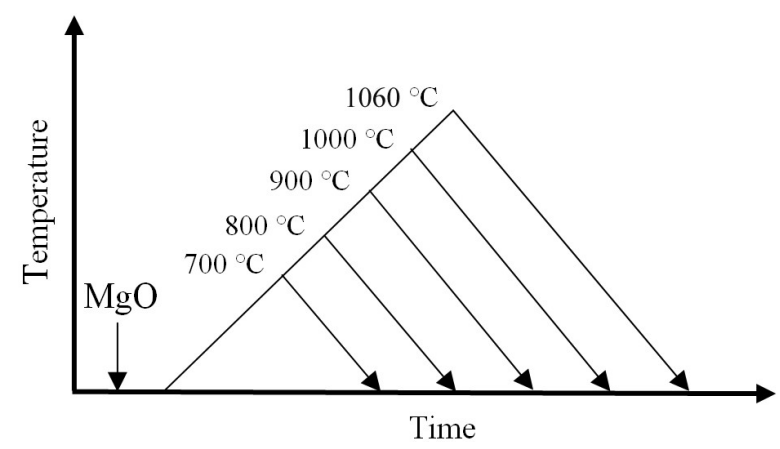

Fig. 1. Schematic presentation of the experiment. 
The surfaces of the initial and heat-treated samples were studied under a scanning electron microscope using energy dispersive X-ray spectroscopy (EDX). An integral depth chemical analysis of the materials in the layers of the samples was carried using glow-discharge optical emission spectroscopy (GDOES) on a GDA-750 [18,21,25]. A Bruker D8 Advance diffractometer and an Anton Paar HTK $1200 \mathrm{~N}$ thermal vacuum chamber were used to perform an X-ray diffraction analysis (XRD) of the samples using $\mathrm{Co}_{\mathrm{Ka}}$-radiation in coldrolled (without coating) and heat-treated states (with coating). The XRD analysis was performed at a temperature of $30^{\circ} \mathrm{C}$. The samples were heated within the temperature range from 780 to $1060^{\circ} \mathrm{C}$ and cooled from 1060 to $780^{\circ} \mathrm{C}$, with measurements taken every $20^{\circ}$, at the maximum possible rate for this type of chamber of $0.5^{\circ} / \mathrm{sec}$.

To theoretically evaluate the phase composition of the surface layers of the metal at high temperatures, calculations of thermodynamic equilibrium were performed using Thermo-Calc software.
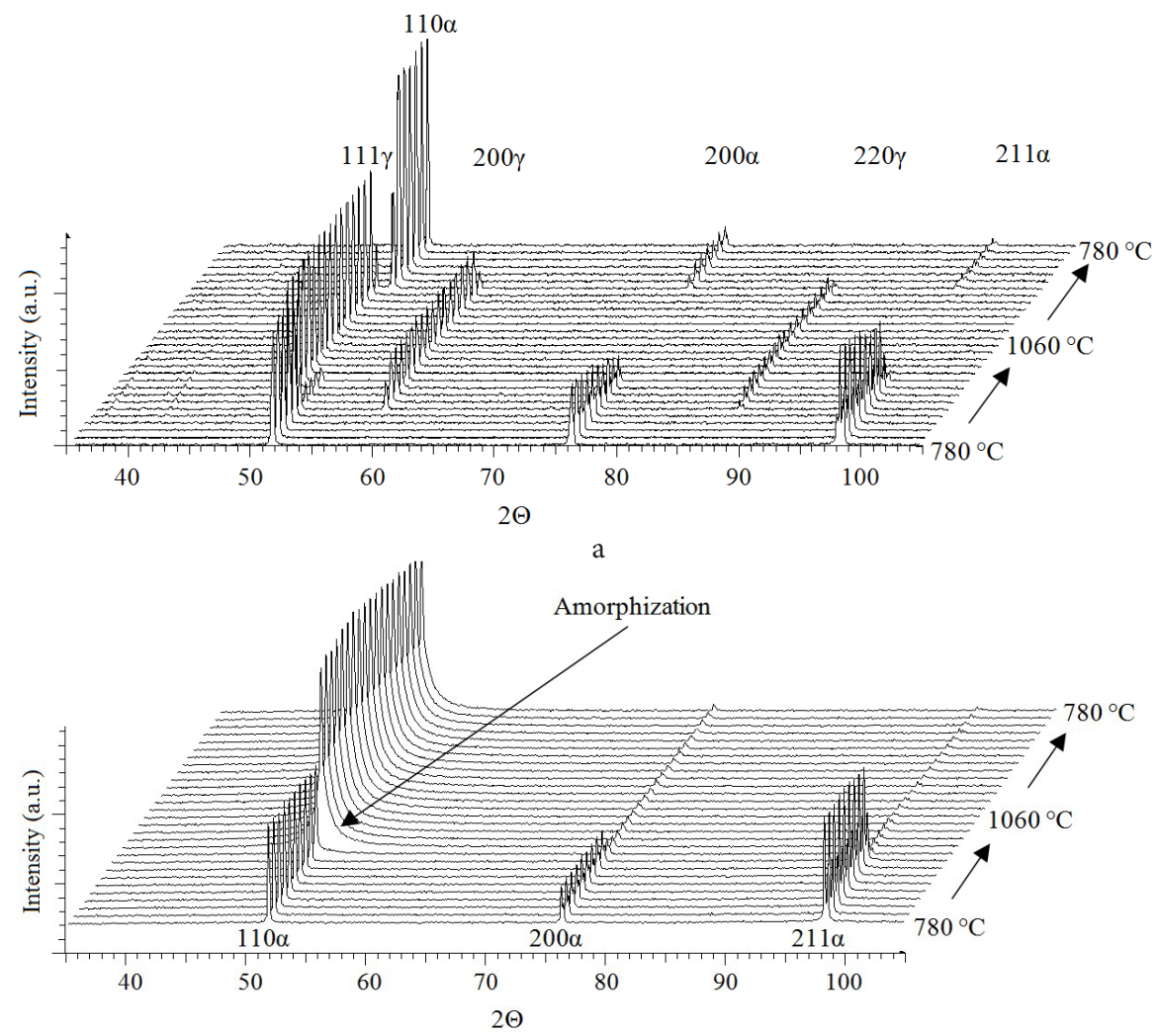

b

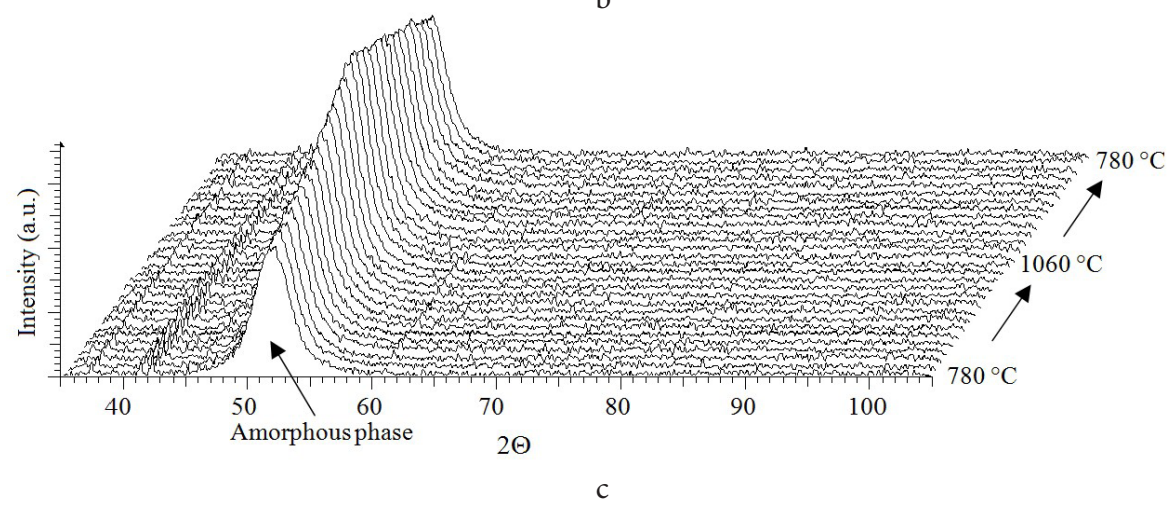

Fig. 2. XRD patterns from the surface of the Fe-3\%Si- $0.5 \% \mathrm{Cu}$ alloy uncoated sample (a); coated sample after $t \leq 780^{\circ} \mathrm{C}$ heating (b); a coated sample after the preliminary cycle of heat treatment $\left(20^{\circ} \mathrm{C} \rightarrow 1100^{\circ} \mathrm{C} \rightarrow 20^{\circ} \mathrm{C}\right)(\mathrm{c})$.

\section{Results}

The surface layer of the samples (internal oxidation zone - IOZ) after decarburizing annealing represented a Fe-based Si-depleted (1-2 wt.\%) solid solution with dispersed oxide precipitates of $\mathrm{Fe}_{2} \mathrm{SiO}_{4}$ on the surface and $\mathrm{SiO}_{2}$ at depth, which corresponds to the results published in $[17,18,20,21]$. Subjected to cold rolling, the layer became thinner in accordance with the strain ratio. At the same time, the quantity of $\mathrm{Fe}_{2} \mathrm{SiO}_{4}$ on the surface marginally decreased.

The results of the XRD analysis of the uncoated samples after heating and cooling $\left(780^{\circ} \mathrm{C} \rightarrow 1060^{\circ} \mathrm{C} \rightarrow 780^{\circ} \mathrm{C}\right.$, with a measurement step of $20^{\circ}$ ) demonstrated the $\alpha \leftrightarrow \gamma$ transition in the temperature range of $920-940^{\circ} \mathrm{C}$ (Fig. $2 \mathrm{a}$ ). It is obvious that austenite in the oxidized surface layer of the $\mathrm{Fe}-3 \% \mathrm{Si}-0.5 \% \mathrm{Cu}$ alloy is formed due to the substantial amount of $\mathrm{Si}$ not only in the solid solution, but also in the oxide phases. It should be also noted that 
the $\alpha \leftrightarrow \gamma$ transformation was observed in $\mathrm{Fe}-3 \% \mathrm{Si}$ with additional $\mathrm{Cu}$ and $\mathrm{Mn}$ dopes, rather than in the conventional Fe-3\%Si alloy.

The non-ambient XRD analysis of the coated samples in the temperature range of $920-940^{\circ} \mathrm{C}$ showed a halo effect near $(110)_{\alpha-\mathrm{Fe}}$, indicating the amorphous state of the material (Fig. 2 b), which maintained during subsequent heat treatment both when heated and when cooled to $30^{\circ} \mathrm{C}$.

In accordance with the GDOES data (Fig. 3), the alloy surface interacted with the coating during heating at different temperatures. Oxygen diffused into the surface at $700^{\circ} \mathrm{C}$, while $\mathrm{O}$ and $\mathrm{Mg}$ diffused together in the temperature interval of $700-900^{\circ} \mathrm{C}$. The ratio of elements in the surface layer indicates that $\mathrm{FeO}$ was predominantly formed in the low-temperature interval (Fig. $3 \mathrm{a}$ ). At higher heating temperatures, $\mathrm{MgO}$ is dissolved in $\mathrm{FeO}$ producing ( $\mathrm{FeMg}) \mathrm{O}$ (magnesiowustite) (Fig. 3b-d). Further interaction of $(\mathrm{FeMg}) \mathrm{O}$ with $\mathrm{SiO}_{2}$ results in the formation of $(\mathrm{MgFe})_{2} \mathrm{SiO}_{4}$ (forsterite). A continuous layer phase, which can be identified as $(\mathrm{MgFe})_{2} \mathrm{SiO}_{4}$, was observed at temperatures above $900^{\circ} \mathrm{C}$.

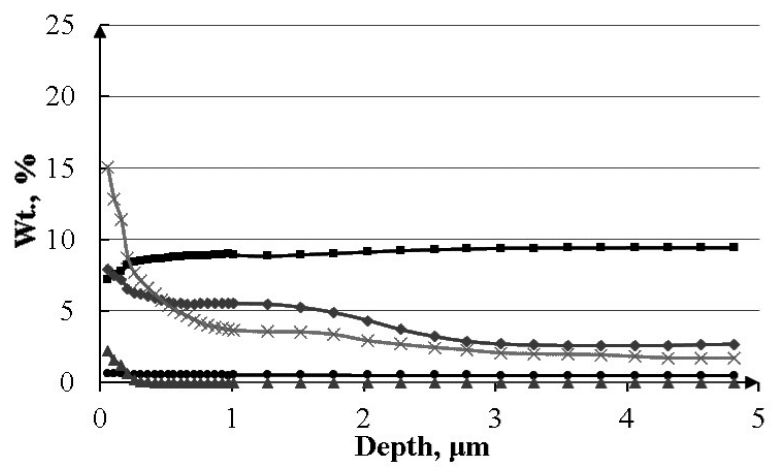

a
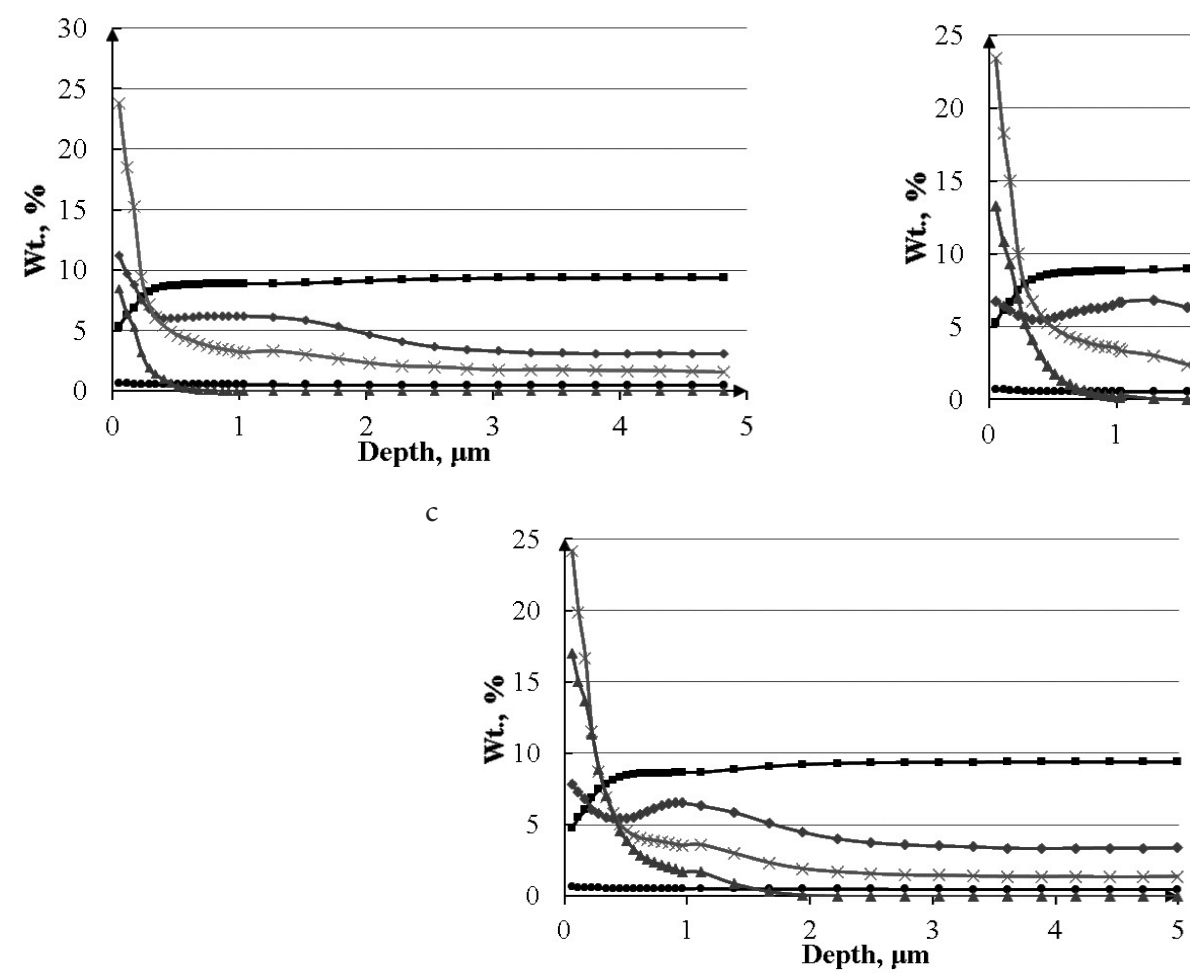

e
Performed for different temperatures of continuous heating (Fig. 4), the metallographic analysis of the surface of the coated samples revealed precipitates in the uniform matrix.

At temperatures not exceeding $900^{\circ} \mathrm{C}$, these precipitates markedly differed in shape and size, from small spherical to large faceted ones. At higher temperatures, only large precipitates with a smoother shape were found in the structure. According to the EDX data, the homogeneous matrix featured a Fe-based solid solution, while all the inclusions consisted of $\mathrm{Si}$-, $\mathrm{Mg}$ - and Fe-based oxide phases. Taking into account the ratio of chemical elements, the darker inclusions supposedly corresponded to $\mathrm{SiO}_{2}$ and the lighter ones to $(\mathrm{MgFe})_{2} \mathrm{SiO}_{4}$ and $(\mathrm{MgFe}) \mathrm{O}$.

To identify the thermodynamically possible phase equilibria using ThermoCalc, we used a concentration of elements measured by GDOES using depth profiling analysis (Fig. 3). The calculations have shown that the zones adjacent to the surface should contain a solid solution based on Fe and $(\mathrm{MgFe})_{2} \mathrm{SiO}_{4},(\mathrm{FeMg}) \mathrm{O}$ oxides at temperatures of about

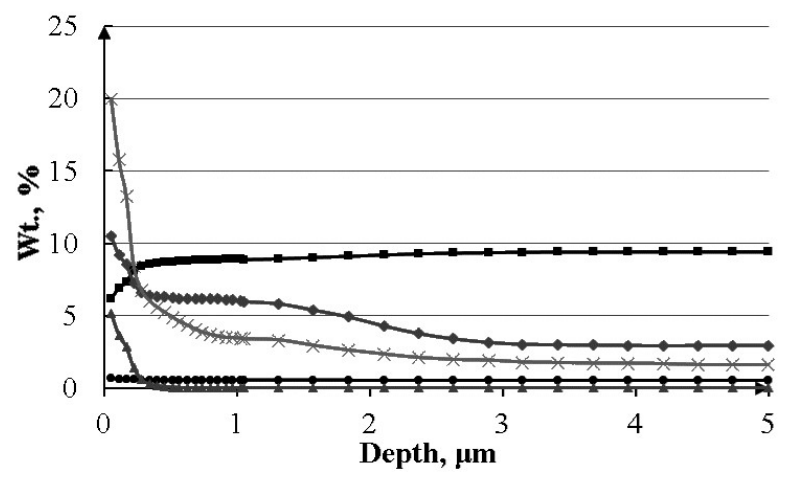

b

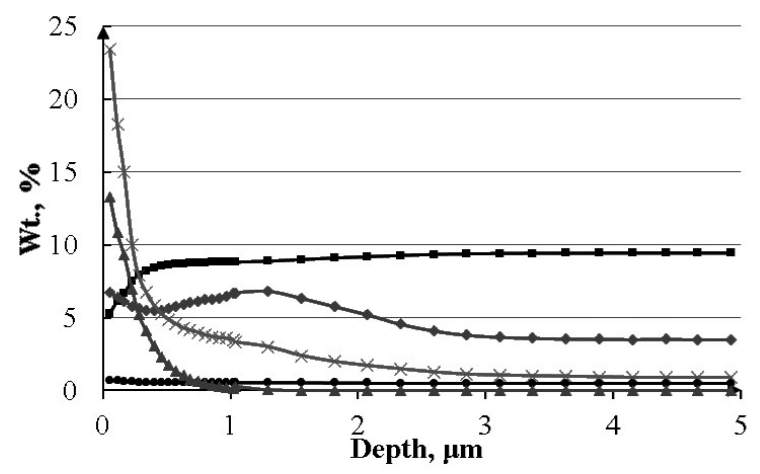

d

Fig. 3. Fe-3\%Si- $0.5 \% \mathrm{Cu}$ alloys with $\mathrm{MgO}$ coating surface layer elements distribution, after continuous heating at $t \leq N^{\circ} \mathrm{C}: 600^{\circ} \mathrm{C}(\mathrm{a}) ; 700^{\circ} \mathrm{C}(\mathrm{b})$; $800^{\circ} \mathrm{C}(\mathrm{c}) ; 900^{\circ} \mathrm{C}(\mathrm{d}) ; 1000^{\circ} \mathrm{C}(\mathrm{e}) ; \mathrm{Fe} \times 0.1 \longrightarrow \longrightarrow ; \mathrm{Si} \longrightarrow ; \mathrm{O}-\longrightarrow \times ; \mathrm{Cu} \longrightarrow \longrightarrow ; \mathrm{Mg} \longrightarrow \longrightarrow$ 

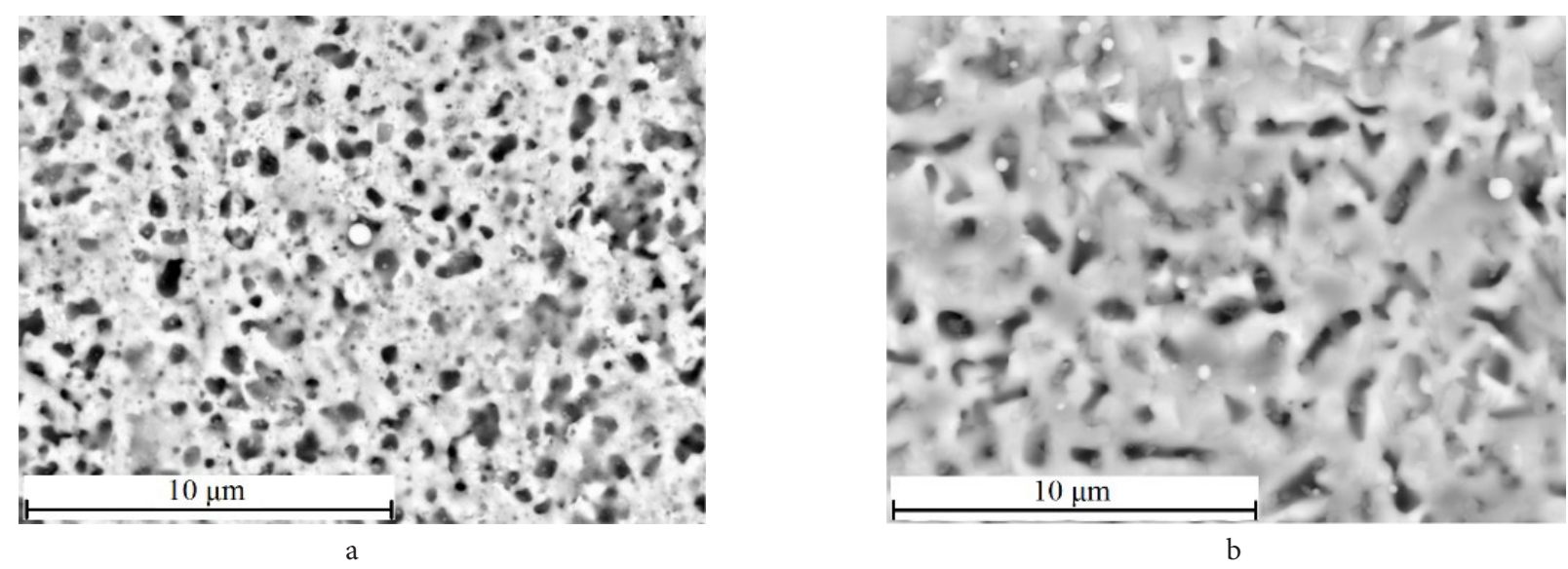

Fig. 4. Surface microstructure of the $\mathrm{Fe}-3 \% \mathrm{Si}-0.5 \% \mathrm{Cu}$ alloy with $\mathrm{MgO}$ coating after continuous heating at: $t \leq 850^{\circ} \mathrm{C}(\mathrm{a}) ; t \leq 1050^{\circ} \mathrm{C}(\mathrm{b})$.

$900^{\circ} \mathrm{C}$. The next zone should contain a solid solution based on $\mathrm{Fe}$ and $(\mathrm{MgFe})_{2} \mathrm{SiO}_{4}, \mathrm{SiO}_{2}$ oxides. The concentration of chemical elements in each region determines the type and the volume fraction of the oxide phases. Therefore, the continuous substitution of the $(\mathrm{MgFe}) \mathrm{O}$ and $(\mathrm{MgFe})_{2} \mathrm{SiO}_{4}$ oxide phases with $(\mathrm{MgFe})_{2} \mathrm{SiO}_{4}$ and $\mathrm{SiO}_{2}$ using depth profiling analysis allows us to identify a thin layer at a distance of about $1 \mu \mathrm{m}$, in which $(\mathrm{MgFe})_{2} \mathrm{SiO}_{4}$ forsterite exists in equilibrium with an amorphous solid solution.

Assuming that there are no oxygen atoms in a solid solution, the composition of the amorphous phase represents the concentration of all atoms in the layer except for forsterite atoms. Based on the study findings, we can describe the composition of the amorphous phase as $\mathrm{Fe}_{89.5} \mathrm{Si}_{6} \mathrm{Mg}_{4} \mathrm{Cu}_{0.5}$.

We assume that the reason why the amorphous phase is formed is that the most dispersed precipitates of $(\mathrm{MgFe})_{2} \mathrm{SiO}_{4}$, $(\mathrm{MgFe}) \mathrm{O}$ decompose as a result of the reduction of positive ions of $\mathrm{Mg}, \mathrm{Fe}$, Si by hydrogen in the temperature range of metastability of the $\alpha$-Fe crystal lattice, which precedes the $a \rightarrow \gamma$ transition. The $\mathrm{Mg}_{2} \mathrm{Si}$ complexes, which diffuse into a solid solution of $\alpha-\mathrm{Fe}(\mathrm{Si})$, are retained at the $(\mathrm{MgFe})_{2} \mathrm{SiO}_{4}$ sites. $\mathrm{Mg}$ ions cause $(\mathrm{MgFe}) \mathrm{O}$ to decompose and diffuse into $\alpha-\mathrm{Fe}(\mathrm{Si})$. This leads to the formation of $\mathrm{Mg}_{2} \mathrm{Si}$ complexes in the solid solution lattice, which is attributed to the formation of strong chemical bonds between $\mathrm{Mg}$ and $\mathrm{Si}$ [27]. $\mathrm{Mg}_{2} \mathrm{Si}$ complexes in a solid solution presumably lead to its amorphization instead of $a \rightarrow \gamma$ transition. Due to the large number of strong chemical bonds between the elements in this amorphous state, it is quite stable both during subsequent heating and during cooling. This mechanism looks similar to diffusion amorphization in different systems [11,12]

The next experiment was carried out to prove the thermal stability of the amorphous state. A thick layer of a heat resistant $\mathrm{MgO}+\mathrm{Mg}(\mathrm{OH})_{2} \times \mathrm{nH}_{2} \mathrm{O}$ coating containing in total about $5 \%$ of $\mathrm{H}_{2} \mathrm{O}$ after drying was applied to the GOES standard plates after decarburizing annealing. First, the samples were heated in a protective atmosphere $\left(75 \% \mathrm{H}_{2}+25 \% \mathrm{~N}_{2}\right)$ at a rate of $0.004 \mathrm{dps}$ from 20 to $1100^{\circ} \mathrm{C}$, after that they were slowly cooled in the furnace for the next 10 hours.

XRD analysis has revealed the amorphous surface layer of at least $2 \mu \mathrm{m}$ in the temperature range used in the experiment. This is supported by the absence of BCC peaks in the diffraction pattern of the Fe-3\%Si plate (Fig. 2c).

\section{Conclusions}

The study of the diffusion interaction between the oxidized surface of $\mathrm{Fe}-3 \% \mathrm{Si}-0.5 \% \mathrm{Cu}$ and the $\mathrm{MgO}$ coating has shown the formation of the $\alpha-\mathrm{Fe}(\mathrm{Si})$ solid solution amorphous phase in the $\alpha \rightarrow \gamma$ transition temperature range. The composition of the amorphous phase can be described as $\mathrm{Fe}_{89.5} \mathrm{Si}_{6} \mathrm{Mg}_{4} \mathrm{Cu}_{0.5}$. The amorphous phase persisted both during heating to a temperature of $1100^{\circ} \mathrm{C}$ and during cooling to room temperature.

It is important to emphasize that the structure obtained by diffusion of Fe-based metallic materials prepares the ground for obtaining thermostable amorphous samples with improved magnetic properties due to the increasing number of metal atoms in a solid solution up to $90 \%$ compared to $80 \%$ in conventional Fe-based metallic glasses [9].

Acknowledgements. This study was conducted using equipment provided by the Laboratory of Structural Analysis Techniques and Materials and Nanomaterials Properties of CKP Ural Federal University. The study was financially supported by Government Decree No. 211 of the Russian Federation, Contract No. 02. A03.21.0006 and within the framework of the state task issued by the Ministry of Education and Science of the Russian Federation, project No. 11.1465.2014/K. The reported study was funded by RFBR, project number 20-08-00332.

\section{References}

1. W. Klement, R.H. Willens, P. Duwez. Nat. 187, 869 (1960). Crossref

2. A. Inoue, A. Takeuchi. Acta Mater. 59, 2243 (2011). $\underline{\text { Crossref }}$

3. K. Suzuki, H. Fujimori, K. Hashimoto. Materials Science of Amorphous Metals (ed. by T. Masumoto). Ohmsha, Tokyo (1982) $281 \mathrm{p}$.

4. E. V. Levchenko, A. V. Evteev, A. R. Yavari, D. V. LouzguineLuzgin, I. V. Belova, G. E. Murch. Philos. Mag. Lett. 93, 50 (2013). Crossref

5. N.N. Nikul'chenkov, A.S. Yurovskikh, Y.N. Starodubtsev, M.L. Lobanov. Lett. Mater. 9 (1), 64 (2019). (in Russian) [Н.Н. Никульченков, А. С. Юровских, Ю. Н. Стародубцев, М.Л. Лобанов. Письма о материалах. 9 (1), 64 (2019).] Crossref 
6. V.Schnabel, M. Köhler, D. Music, J. Bednarcik, W. J. Clegg, D. Raabe, J. M. Schneider. J. Phys.: Condens. Matter. 29, 265502 (2017). $\underline{\text { Crossref }}$

7. B.Zang, R. Parsons, K. Onoder, H. Kishimoto, A. Kato, A.C. Y. Liu, K. Suzuki. Scripta Mater. 132, 68 (2017). Crossref

8. K. Suzuki, R. Parsons, B. Zang, K. Onodera, H. Kishimoto, A. Kato. Appl. Phys. Lett. 110, 012407 (2017). Crossref

9. C. Suryanarayana, A. Inoue. Inter. Mater. Rev. 58 (3), 131 (2013). Crossref

10. R. B. Schwarz, W. L. Johnson. Phys. Rev. Lett. 51 (5), 415 (1983). Crossref

11. B.X. Liu, W.S. Lai, Z. J. Zhang. Adv. Phys. 50 (4), 367 (2001). Crossref

12. H. Gavrila, V. Ionita. Journal of Optoelectronics and Advanced Materials. 4, 173 (2002).

13. Y.R. Zhang, R. V. Ramanujan. J. Mater. Sci. 41, 5292 (2006). Crossref

14. L. Morsdorf, K. G. Pradeep, G. Herzer, A. Kovács, R. E. Dunin-Borkowski, I. Povstugar, G. Konygin, P. Choi, D. Raabe. J. Appl. Phys. 119, 124903 (2016). Crossref

15. V. Schnabel, M. Kohler, S. Evertz, J. Gamcova, J. Bednarcik, D. Music, D. Raabe, J. M. Schneider. Acta Mater. 107, 213 (2016). Crossref

16. M.L. Lobanov, G.M. Rusakov, A.A. Redikul'tsev. Met. Sci. Heat Treat. 53, 326 (2011). Crossref
17. G.S. Korzunin, M.L. Lobanov, A.A. Redikultsev, L. V. Lobanova. Russ. J. Nondestr. Test. 50, 585 (2014). Crossref

18. M.L. Lobanov, A. S. Yurovskih. Met. Sci. Heat Treat. 58, 5667 (2017). Crossref

19. T. Takamiya, K. Hanazawa, T. Suzuki. JFE Technical Report. 21, 1 (2016).

20. S. Fortunati, G. C. Abbruzzese, S. Cicalè. New Frontiers for Grain Oriented Electrical Steels: Products and Technologies. 7th International Conference on Magnetism and Metallurgy (2016) Terni, Italy.

21. S. Jung, M. S. Kwon, S. B. Kim, K. S. Shin. Surface Interface Analysis. 45, 1119 (2013). $\underline{\text { Crossref }}$

22. S. Jung, M.S. Kwon, J. Park, S. B. Kim, Y.Huh. ISIJ International. 51, 1163 (2011). $\underline{\text { Crossref }}$

23. P. Rodriguez-Calvillo, E. Leunis, T. Van De Putte, S. Jacobs, O. Zacek, W. Saikaly. AIP Advances. 8, 047605 (2018). Crossref

24. H. Toda, K. Sato, M. Komatsubara. J. Mater. Eng. Perform. 6, 722 (1997). $\underline{\text { Crossref }}$

25. M. L. Lobanov, A. I. Gomzikov, S. V. Akulov, A. I. Pyatygin. Met. Sci. Heat Treat. 47, 478 (2005). Crossref

26. T. Yi, S. Chen, S. Li, H. Yang, S. Bux, Z. Bian, N. A. Katcho, A. Shakouri, N. Mingo, J. Fleurial, N. D. Browning, S. M. Kauzlarich. J. Mater. Chem. 22, 24805 (2012). Crossref 